Published by the University of KwaZulu-Natal https://journals.ukzn.ac.za/index.php/JICBE (C) Creative Commons With Attribution (CC-BY) Journal of Inclusive cities and Built environment. Vol. 2 Issue 1

How to cite: J. Kamuzhanje. 2022. Inclusive Cities, Urban Housing and Disability: Unmasking the Political Economy of Urban Housing Provision for People with Disability in Urban Settlements in Zimbabwe. Conference Proceedings for International Symposium on Inclusive-Cities: Achieving Inclusive Cities Through A Multidisciplinary Approach, 2021 28-30 June. Journal of Inclusive cities and Built environment. Vol. 2 Issue 1, Pg 35-40.

\title{
INCLUSIVE CITIES, URBAN HOUSING AND DISABILITY: UNMASKING THE POLITICAL ECONOMY OF URBAN HOUSING PROVISION FOR PEOPLE WITH DISABILITY IN URBAN SETTLEMENTS IN ZIMBABWE
}

\author{
By J. Kamuzhanje
}

Published 31 January 2022

\begin{abstract}
Any discussion on urban development in general, and urban housing in particular, is hedged against Sustainable Development Goal 11 "Make cities and human settlements inclusive, safe, resilient and sustainable". However, the goal becomes even more poignant when issues of inclusivity and disability are considered. Housing, whether in rural or urban areas, is a basic right. The world over, governments have institutionalised and constitutionalised housing as a basic and human right. According to Habitat for Humanity, its vision is a world where everyone has a decent place to live. The reality, however, is that housing provision is a major challenge. The growing waiting lists, the sprouting illegal settlements, the increasing number of housing estates which are on unserviced land, points to a social, economic and health ticking bomb. The issues of urban housing become even more complicated and sophisticated when issues of disability come into play. The mantra behind inclusive cities focuses on the "right to the city" for all. Whilst this is a noble idea, it is also apparent that the concept is not absolute. This is because the city, and housing provision, is still not designed for people with disability. The services that the city provides, including housing, do not take into account the challenges that people with disability face in accessing them. The paper focuses on the political economy of urban housing in Zimbabwe, with particular attention paid to people living with disability. The main argument proffered is that urban development and urban design must accommodate the housing needs of people living with disability. This is the only way that the city can become "inclusive, safe, resilient and sustainable".
\end{abstract}

KEY WORDS disability, housing, inclusive, right to the city, universal design

Joseph Kamuzhanje: Professor of Practice in Regional and Urban Planning (University of Venda, South Africa), Cooper Zimbabwe. 


\section{INTRODUCTION}

Sustainable Development Goal 11 expresses the need for cities and human settlements to be inclusive, safe, resilient, and sustainable. Indicator 11.2 states that, "By 2030, provide access to safe, affordable, accessible and sustainable transport systems for all, improving road safety, notably by expanding public transport, with special attention to the needs of those in vulnerable situations, women, children, persons with disabilities (my bold and underline) and older persons. The Vancouver Declaration on Human Settlements (1976) echoes the same sentiments, ".....there is need for awareness of and responsibility for increased activity of the national governments and the international community, aimed at mobilization of economic resources, institutional changes and international solidarity by:....creating more liveable, attractive and efficient settlements which recognize human scale, the heritage and culture of people and the special needs of disadvantaged groups especially children, women and the infirm..."

The word "inclusive" appears more times (7) than any other word in the 17 SDG goals. This does not include the number of times when it is indirectly referred to and replaced by words such as "all". If anything, this points to the focus of the sustainable development agenda till 2030, which is to ensure that every person gets an equal chance and opportunity in every sphere of life. The plight of the people living with disability has been worsened by the fact that the rate of urbanisation has increased at unprecedented levels. Between 1990 and 2015 , the rate of urbanisation has increased from $33.9 \%$ to $57.1 \%$ and is projected to continue increasing as rural poverty continues to manifest itself. This has put a lot of pressure on the provision for services, especially housing, but has also created a situation where the needs and priorities of the disadvantaged members of the urban settlements as their issues are not always at the top of the development agenda.

\section{THE RIGHT TO THE CITY}

The concept of the right to the city was popularised by Lefebvre (1968) and in later writings by Schmid (2017), Harvey (2008) and Purcell (2002). According to Lefebvre, the right to the city was far more than the individual liberty to access urban resources: "it is a right to change we by changing the city. It is, moreover, a common rather than an individual right since this transformation inevitably depends upon the exercise of a collective power to reshape the processes of urbanization. The freedom to make and remake our cities and ourselves is, I want to argue, one of the most precious yet most neglected of our human rights". The advocacy for the right to the city was a rejoinder to what was seen as a "crisis of the city." The crisis consisted primarily of a tendency towards the homogenization of lifestyles and an engineering and colonization of daily life. According to Lefebvre, this situation was untenable, and he therefore "demanded" the right to the city which meant that every citizen had the right not to be displaced into a space produced for the specific purpose of discrimination.

According to Harvey, the right to the city is more than just people being able to access the goods and services that city offers. He contends that the right to the city is a right "to change ourselves by changing the city more after our heart's desire. It is, moreover, a collective rather than an individual right since changing the city inevitably depends upon the exercise of a collective power over the processes of urbanization. The freedom to make and remake ourselves and our cities is, I want to argue, one of the most precious yet most neglected of our human rights." Habitat III (2016) takes this argument even further by making the observation that in the concept of cities for all (right to the city), "there is need) to promote inclusivity and ensure that all inhabitants, of present and future generations, without discrimination of any kind, are able to inhabit and produce just, safe, healthy, accessible, resilient, and sustainable cities and human settlements, as a common good that essentially contributes to prosperity and quality of life. This is based on a peoplecentred vision of cities as places that strive to guarantee a decent and full life for all inhabitants."

According to Magidimisha, Chipungu and Kamuzhanje (2019), the concept of the right to the city should be supported in no small measure by the idea of social justice. Discussing the city and housing development and, quoting Rawls (1971) the authors contend that social justice should be viewed as a systematic form of justice applied to society as a whole with an emphasis on equal distribution of resources on the basis of individual requirements, but with a focus on the disadvantaged and equality of opportunities. The key point about this view of social justice is the emphasis on the disadvantaged. This is important because they have normally been left out of the discussions, and this has meant that their issues have not been adequately addressed.

\section{THE RIGHT TO HOUSING}

The right to adequate housing is clearly recognized in international human rights law, including in the International Covenant on Economic, Social and Cultural Rights, which provides for "the right of everyone to an adequate standard of living for himself and his family including adequate food, clothing and housing, and to the continuous improvement of living conditions" (art. 11.1). Yet, well over one billion people live in precarious conditions in slums and informal settlements threatening their health and even their survival. In addition, some 100 million are homeless on any given day. Further millions are forcibly evicted or displaced from their homes every year. A gender analysis indicates that women are particularly affected, but women with disability are in an even more precarious position.

\section{UNIVERSAL DESIGN}

One concept which is very important in understanding inclusivity in urban environments is that of universal design. This is a concept popularised by Ronald Mace. According to Mace, universal design ensures that products and buildings can be used by virtually everyone, regardless of their level of ability or disability. Urban design means designing all products, buildings, and exterior spaces to be usable by all 
people to the greatest extent possible, and is based on the following widely accepted principles:

- Disability is not a special condition of a few.

- It is ordinary and affects most of us for some part of our lives.

- If a design works well for people with disabilities, it works better for everyone.

- Usability and aesthetics are mutually compatible.

The concept of universal design suffers from a number of challenges, the primary one being that in most countries, most buildings, both public and private were not designed with disability in mind. Whilst the laws of those countries make provisions for adjustment orders, there is rarely the political and economic will to enforce these provisions. In most cases, it is the same governments that fall foul of their own laws because they do not have the resources to put in place the necessary and appropriate adjustments and measures. The implications for adhering to the concept of universal design are that this has to be done whilst respecting the seven common principles that are used to assess whether universal design has been achieved or not (Vermont, 2015): (i) equitable use (ii) flexibility in use (iii) simple and intuitive use (iv) perceptible information (v) tolerance of error (vi) low physical effort (vii) size and space for approach and use. The interesting observation about these principles is that if they are applied, they actually improve the performance of the city. These principles dovetail very well with the four key design principles for urban areas: safety, convenience, order, and aesthetics.

\section{INCLUSIVITY IN HOUSING PROVISION}

The concept of inclusivity focuses on the need to make sure that the city is designed so that it meets the needs of all people and does not discriminate in terms of who should access the services offered. According to Kamuzhanje (2020), in Chipungu and Magidimisha (2020), inclusivity is made up of four pillars: accessibility, affordability, resilience and sustainability. The pillars can be represented diagrammatically as follow.

Figure 1: The four pillars of inclusivity

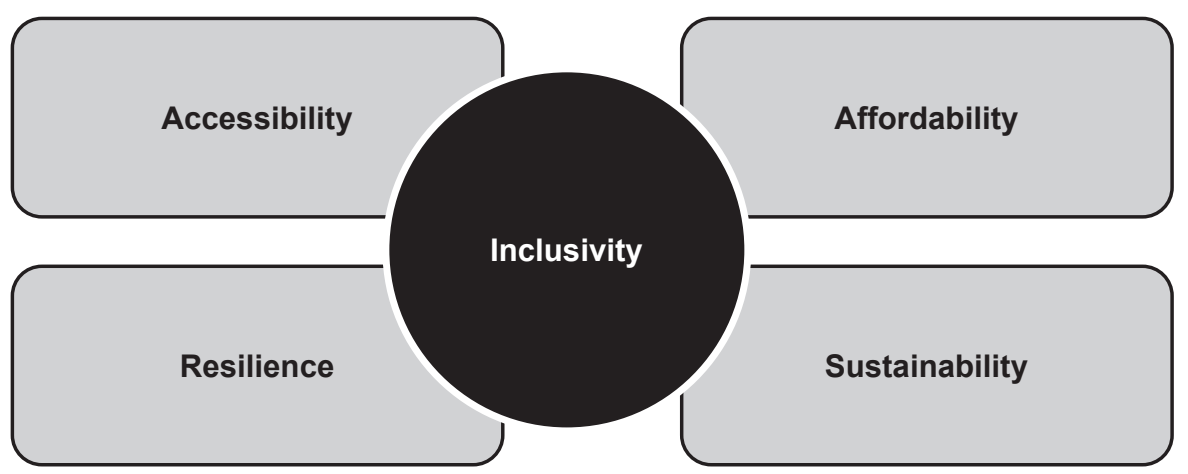

Source: Author's construct, August 2020.

An inclusive city, therefore, creates a safe, liveable environment with affordable and equitable access to urban services, social services, and livelihood opportunities for all the city residents and other city users to promote optimal development of its human capital and ensure the respect of human dignity and equality.

\section{ISSUES FOR CONSIDERATION IN HOUSING PROVISION FOR PEOPLE WITH DISABILITY}

There are a number of critical issues that exclude people with disability from participating actively in the housing sector. This is against the background of an immense scale of the housing challenge (King, et.al., 2017). The urban population is expected to grow by about 2.5 billion people by 2050 , and about 90 percent of this growth is expected to occur in Asia and Africa. The share of the population that is poor is growing in urban areas, compounding the pressure of population growth. The challenge is how to ensure that the needs and priorities of people with disability are taken into account.

\section{THE POLICY AND LEGISLATIVE FRAMEWORK}

One of Zimbabwe's pieces of legislation, the Disabled Persons Act Chapter 17:01 of 1992, defines a person living with disability as:

...a person with a physical, mental or sensory disability, including a visual, hearing or speech functional disability, which gives rise to physical, cultural or social barriers inhibiting him from participating at an equal level with other members of society in activities, undertakings or fields of employment that are open to other members of society (Section 2).

The rights and privileges of the people living with disability in Zimbabwe are enshrined in the Constitution of Zimbabwe (2013). According to Section 22 of the Constitution, Zimbabwe has committed itself to.... (1) recognise the rights of persons with physical or mental disabilities, in particular their right to be treated with respect and dignity, and (2)...within the limits of the resources available to them, assist persons with physical or mental disabilities to achieve their full potential and to minimise the disadvantages suffered by them. Specifically, clauses 22(3)(b) and 24 focus on consider the specific requirements of persons with all forms 
of disability as one of the priorities in development plans and take appropriate measures to ensure that buildings and amenities to which the public has access are accessible to persons with disabilities, respectively.

The Zimbabwe National Human Settlements Policy (2019) advocates for local authorities to "liaise with national institutions leading on relevant social protection policies and standards so that their actions are sensitive to gender, youth, social, disability and child protection needs. Universal design principles and good practices shall be applied. Local authorities will develop and apply social inclusion policies that are responsive, preventative, and transformative covering key decisionmaking areas. Application of the policies will be evidenced in budgets, service delivery approaches and infrastructure design e.g. building access." Whilst this is so on paper, a key challenge has been putting this into practice. Very few local authorities, if any, have made a deliberate attempt to promote the housing needs of people with disability.

\section{AVAILABILITY OF RELIABLE DATA ON PEOPLE WITH DISABILITY}

One of the key determinants of service provision is reliable data and information. Most developing countries, Zimbabwe included, do not have upto-date data that is important to shape the growth and development of urban settlements. This makes it very difficult to plan for the provision of housing and other services for urban residents and even, more so, for people with disability. Currently, local authorities in Zimbabwe are using the 2012 National Population Census results to forecast the number of people that require their services. With all the changes that have happened, and movement of people to and from urban areas, the data is unusable. The estimates for the population for any urban settlement are not even close to the real situation on the ground. It is almost impossible to find a local authority that has records of the number of people with disability living within its areas of jurisdiction. This makes it difficult to plan for them.

\section{ACCESS TO FINANCE}

A key factor in accessing housing is finance. The Zimbabwe housing sector has suffered over the years due to the poor economic performance. The interest regime has become so high that it is not possible to borrow in order to build a house. In addition, due to the fluctuations in the currency, very few banks and building societies are giving out mortgages and bonds. In any case, even if the mortgage finance was available, all the banks insist on collateral. The Government of Zimbabwe has even passed a Movable Property Act. The Act is supposed to allow individuals to use movable assets as collateral. However, the people with disability will not have access to movable property and will miss out as a result. All these factors militate against access to housing especially by people with disability. Most of the people with disability are not in gained employment and would not have the resources to finance the loans. Even though the Reserve Bank of Zimbabwe (RBZ) has a National Financial Inclusion Strategy, whose vision is "To have an inclusive financial system that is responsive to the needs of all Zimbabweans", there is no specific and direct mention of people with disability as a special interest group in the document. As long as there is no deliberate attempt to actively develop financial models that serve the interests of people with disability, then their plight can only get worse.

\section{WOMEN WITH DISABILITY AND HOUSING}

Women in general, have challenges accessing services and bear the brunt of poverty and poor service delivery. However, the plight of women with disability is even worse. According to Meekosha (2004), women with disability have serious disadvantages in society.

- More women than men are classified as disabled, particularly as ageing populations mean that larger proportions of the elderly are women with impairments.

- While disabled people are much more likely to live in poverty, women are likely to be poorer than men; especially in developing countries where women are often heads of households.

- Younger disabled women achieve lower educational outcomes than men.

- Disabled women are less likely to be in the paid workforce than either men with disabilities for non-disabled women, and, in general have lower incomes from employment.

- Disabled women are more likely to be living on their own, or in their parental family than men.

- $\quad$ Disabled women are more likely to be divorced and less likely to marry than men with disabilities

Therefore women with disability are more likely to find it difficult to access housing that is appropriate and affordable.

\section{HOUSING AND ESTATE DESIGN}

One of the key areas of debate in housing provision has been densification. Densification has been promoted as a tool against urban sprawl. In principle, this is a very noble proposition as besides controlling the outward expansion of urban settlements, densification also results in cutting the costs of infrastructure provision. With densification, the provision of water, electricity, sewerage services and roads becomes reasonably cheaper. However, for people with disability, this may cause challenges depending on how the densification is carried out. In Harare and most urban settlements in Zimbabwe, densification has been synonymous with vertical development, in the form of flats. This poses a great challenge in terms of accessibility of the houses. Unless appropriate assistive devices are provided, it is very easy to exclude people with disability from this type of housing. 


\section{CONCLUSION}

Housing is a basic human right. However, its provision is a function of a number of critical elements that have been discussed in this paper. Most urban local authorities are struggling to provide adequate and affordable housing to their residents. People living with disability are most affected by lack of affordable and accessible housing. In most cases, the planning, designing and development does not take into account their special needs. The issues highlighted in this paper require a multi-faceted, multistakeholder and multi-institutional approach to effectively address them. 


\section{REFERENCES}

Chipungu, L. J Kamuzhanje, H Magidimisha (2019) Densification, Right to the City and Developments in Harare

Government of Zimbabwe (2016) Zimbabwe National Financial Inclusion Strategy, 2016-2020

Gupta, J., \& Vegelin, C. (2016). Sustainable development goals and inclusive development. International environmental agreements: Politics, law and economics, 16(3), 433-448.

Habitat for Humanity (2012) Global Housing Indicators: Evidence for Action

Harvey, D. (2020). "The Right to the City": New Left Review (2008). In The City Reader (pp. 281-289). Routledge.

King, R., Orloff, M., Virsilas, T., \& Pande, T. (2017). Confronting the urban housing crisis in the global south: adequate, secure, and affordable housing. World Resources Institute Working Paper.

Meekosha (2004) Gender and Disability, New South Wales.

Mugumbate, J., \& Nyoni, C. (2014). Disability in Zimbabwe under the new constitution: Demands and gains of people with disabilities. Southern Peace Review Journal (Special Issue in association with the OSSREA Zimbabwe Chapter) 178: 1.

Rawls J. (1971). A Theory of Justice. Cambridge, Mass: The Belknap Press of Harvard University Press. USA.

Schmid, C. (2012). Henri Lefebvre, the right to the city, and the new metropolitan mainstream. In Cities for people, not for profit (pp. 54-74). Routledge.

UN-Habitat (2016) Habitat III: The New Urban Agenda, Quito.

United Nations (2015) Open Working Group of the General Assembly on Sustainable Development Goals. Available at: http://undocs.org/A/68/970
Alston, P. (1979). The United

Nations' Specialized Agencies and Implementation of the International Covenant on Economic, Social, and Cultural Rights. Colum. J. Transnat'l L., $18,79$.

UNHCR (2012) Women and the Right to Adequate Housing.

World Health Organization. (2011). World report on disability 2011. World Health Organization. 